\title{
What to expect when you are expecting : preferences for representation among voters and political elites
}

\section{Wass, Hanna}

Edward Elgar

2020-12-08

Wass, H \& Nemcok , M 2020 , What to expect when you are expecting : preferences for representation among voters and political elites . in M Cotta \& F Russo (eds), Research Handbook on Political Representation. Elgar Handbooks in Political Science, Edward Elgar , pp. 326-337 . https://doi.org/10.4337/9781788977098.00035

http://hdl.handle.net/10138/325348

https://doi.org/10.4337/9781788977098.00035

Downloaded from Helda, University of Helsinki institutional repository.

This is an electronic reprint of the original article.

This reprint may differ from the original in pagination and typographic detail.

Please cite the original version. 


\title{
What to expect when you're expecting: Preferences for representation among voters and political elites
}

\author{
Hanna Wass \\ https://orcid.org/0000-0002-2429-8062 \\ University of Helsinki \\ Miroslav Nemčok \\ https://orcid.org/0000-0003-3556-5557 \\ University of Helsinki
}

\begin{abstract}
Like any reciprocal relationship, representation is filled with expectations. Different types of voters have different types of ideas on how elected politicians should behave in their role as representatives and what should be considered to be the primary focus of representation. On the other hand, candidates running for elections or MPs already familiar with real-life decision-making situations have their own perceptions. The extent to which these preferences match with each other, in turn, is pivotal for the process legitimacy of representative democracies. In this review chapter, we first discuss the congruence in representational preferences from a conceptual and methodological perspective: how can whether voters and politicians have overlapping expectations of representational roles be measured, and what does congruence mean in the context of representational preferences. Second, we review the findings of those relatively few previous analyses that have examined the question of whether voters and elected representatives have congruent preferences for the style and focus of representation. Third, we address the implications of voter-elite congruence for citizens' satisfaction with the performance of democratic regimes. This is followed by a concluding section, which looks ahead and asks: What can be expected from future studies of congruence in representational expectations and preferences?
\end{abstract}

Keywords: citizens; political elites; representational styles; preferences for political representation; representational congruence; satisfaction with democracy

Political representation is ultimately based on a reciprocal relationship between a principal and an agent (Urbinati and Warren 2008, p. 398). Like in any relationship, both parties have expectations concerning its shape and substance. The extent to which these expectations overlap or diverge influences the perceived functionality of the relationship. In the case of political representation which takes place within elected institutions, the principal-agent relationship is formalized in legislation (Castiglione and Warren 2019, p. 22). This further means that implications of well- or poorly functioning relationship are even wider, extending to the overall satisfaction with representational democracy. If elected representatives continuously make claims concerning their representational roles which are not acknowledged or accepted by their constituencies (cf. Saward 2010, p. 36), the legitimacy of the entire democratic process will eventually suffer. Another layer of complexity stems from the dynamic character of political representation (cf. Dalton et al. 2011, p. 24): representational preferences are not stable but transform themselves depending on policy issues at hand and the context of the decision-making practices. In a nutshell, political representation is an ongoing endeavor, 'constituted not simply by the self-understanding of the representative, but also the expectations of the represented' (Castiglione and Warren 2019, p. 35).

To make things even more complicated, there are multiple ways to understand even constitutionally defined representational roles (see Mansbridge 2003). Voters have different ideas on how elected 
politicians should behave in their role as representatives and what should be considered to be the primary focus of representation. MPs already familiar with real-life decision-making situations might have other kinds of preference. Candidates running for election could lie somewhere in between. Its multifaceted essence makes the empirical study of representational preferences and expectations a highly demanding yet ever more vital task. Furthermore, as there are multiple ways to measure congruence (see Golder and Stramski 2010), and the satisfactory level of congruence is subjected to discretion, the functionality of representational relationship is difficult to evaluate precisely.

In this article, we bound three strains of the literature together. First, the congruence in representational preferences is discussed from a conceptual and methodological perspective: how can it be measured whether voters and politicians have overlapping expectations about representational roles, and what does congruence mean in the context of representational preferences? Second, we reviewed the findings of those relatively few analyses that have examined the question of whether voters and elected representatives have congruent preferences for the process of representation, that is, the way elected representatives should carry out their work. Third, we consider congruence in representational expectations from the perspective of satisfaction with democracy: should we expect a positive or negative link between congruence and satisfaction, and why? The concluding section addresses the question posed in the title from a scholarly perspective: What can be expected in future studies of congruence in representational expectations and preferences?

\section{$<a>$ Congruence in preferences for representation: conceptual and methodological framework}

The first challenge in any study of representational preferences is to define what is meant by representative role(s). As Castiglione and Warren (2019, p. 35) remark, even formal roles like those of MPs' are 'typically subject to conflicting expectations, with many possible ways to understand duties and responsibilities'. As a point of departure, a distinction needs to made between normative roles, deriving from democratic theory (e.g., Ankersmit 2002; Dovi 2007; Mansbridge 2003; Pitkin 1967), and more pragmatic task definitions and work performances (e.g., Esaiasson 2000).

In theoretical accounts, the focus of representation is usually differentiated from the style of representation (Eulau et al. 1959, p. 744), treating these two as separate, although closely related fields. Focus can be further classified into several subcategories, such as national representation of all citizens, geographical representation of one's own constituency, party representation and interest representation of various religious, social, economic and ideological groups (see, e.g., Brack et al. 2012; Eulau and Karps 1977, p. 248; von Schoultz and Wass 2016, p. 139-40). The style of representation, in turn, refers to classic controversy between the delegate and trustee models. This was first formulated by Edmund Burke in 1774 is his famous speech in Bristol:

Parliament is not a congress of ambassadors from different and hostile interests; which interests each must maintain, as an agent and advocate, against other agents and advocates; but parliament is a deliberative assembly of one nation, with one interest, that of the whole; where, not local purposes, not local prejudices, ought to guide, but the general good, resulting from the general reason of the whole (see Kurland and Lerner 1987, p. 448).

However, as most constitutions define members of parliament as independent actors bound only by their own conscience, this distinction is often considered to be redundant in the empirical study of representation (Stimson 2007, p. 851). 
In a similar fashion, it has been pointed out that theory-driven empirical analysis of MPs' representational roles can easily be criticized as an abstract academic exercise which is untouched by the reality of a political process characterized by strong political parties (Carman 2006, p. 104, for defence, see also Carman 2007). As major theories of political representation were formulated prior to the formation of modern parties (Thomassen 1994, p. 250), they tend to emphasize a dyadic relationship between the principal and the agent at the expense of collective representation. In contrast, the model of party representation describes a practice of representation rather than forming a theory by itself (Brito Vieira and Runciman 2008; Judge 1999, p. 71). With the extension of suffrage and the increasing role of parties in elections especially in closed-list PR systems, MPs became more coordinated in their decision-making and parties gradually began to control the entire process of representation (Méndez-Lago and Martínez 2002). This is reflected in recent empirical studies concentrating solely on the preferences for modes of party representation, such as partisans, delegates or trustees (Önnudóttir 2016) or promise-keeping, responsiveness to public opinion and enacting the common good (Werner 2019), and government representation (Bowler 2017).

\section{$<b>$ How can congruence in representational preferences be measured?}

As every topic in empirical social science research, measuring congruence between citizens' and MPs' representational preferences is subjected to often tricky methodological considerations. Many relevant methodological topics related to studying policy congruence, i.e. issue agreement, between voters and representatives are covered in the chapter by Louwerse and Andeweg (2020) included in this volume. Here, we will thus focus more on the specific question related to measuring non-policy congruence. Much like the research on policy congruence, studies of voter-MP congruence rely on surveys conducted among representatives and the public with identical question(s). The opinions on the side of voter(s) and representative(s) are then compared against each other (as has been done by Campbell and Lovenduski 2015; Méndez-Lago and Martínez 2002; von Schoultz and Wass 2016). The comparison is relatively straightforward if an opinion of a voter from one constituency is directly linked to their elected representative in a single member district (Hurley 1982; Weissberg 1978). However, the situation becomes more complicated once representatives are perceived as a collective body (Andeweg 2011; Pitkin 1967: 168-225; Weissberg 1978) which is then scrutinized vis-à-vis the collective opinion of citizens. In that case, it is no longer an individual MP, but a political party, a group of policymakers or an entire assembly whose perception of representation should be matched to voters' expectations. Neither is it possible to measure congruence without aggregating the preferences of both groups.

The prevailing methodological approach to determine voter-representative congruence is to measure the distance between the opinion of the median citizen and the median representative. Such congruence can be measured either in absolute or relative terms (Golder and Stramski 2010). Whereas with the former one subtracts the opinion of the median citizen from the opinion of the median representative on a pre-defined ideational dimension, the latter also considers the dispersion in the opinions of citizens, representatives, or both, along the ideational dimension. Although both approaches are fully legitimate depending on the theoretical framework and research problem at hand, Golder and Stramski (2010, p. 90) argue that 'a concept of relative congruence is typically more appropriate for scholars interested in evaluating how well representatives are performing at producing congruence than the more common concept of absolute congruence'.

While survey data allow either a simple comparison between representational preferences among voters and representatives or a methodologically more sophisticated analysis of congruence, they come with several limitations. First, survey data are not always sufficiently detailed to test all aspects of representational theory. For instance, Weissberg's seminal piece (1978) distinguishes between 
dyadic and collective representation. The former posits that representatives act on behalf of their specific constituencies whereas the latter perceives MPs as a collective body representing society as a whole (Andeweg 2011; Hurley 1982; Miller and Stokes 1963; Pitkin 1967, p. 168-225). Even though there are plausible arguments on why either one should prevail, survey data are too hazy and social reality too dynamic to clearly disentangle which approach is dominant among citizens and representatives (cf. Reher 2016, p. 45).

Second, formulating questions on representational preferences is a highly demanding task as citizens and political elites might not understand the concepts in an identical manner. In order to avoid ambiguity, representational roles need to be described as relatively simple either-or ideal types at the expense of nuances, which are often essential in complex decision-making situations in which representatives hold several roles simultaneously (see e.g., Bengtsson and Wass 2011; Bowler 2017; Carman 2006). This is particularly the case with the style of representation, which is more difficult to measure than the focus of representation. Studies of representational styles usually boil down to a distinction between mandate and independency. Werner (2019) distinguishes between (1) promise keeping - representatives act in accordance with their election pledges, (2) responsiveness to public opinion - representatives reflect the current opinion of their voters, and (3) enacting the common good - representatives act in the interest of the common good. In a corresponding manner, Dassonneville et al. (2020) make a distinction between preferences for MPs (1) to do what they promised during the election campaign (promissory mandate), (2) to act in line with the preferences of the majority of citizens in their constituency (opinion mandate), and (3) to follow their own conscience (trustee mandate). An attempt to measure preferences for these options soon runs into methodological obstacles. If each of them is assessed separately, respondents, i.e. voters and representatives alike, may rate all three as being equally important (cf. Bengtsson and Wass 2011). If respondents are requested to rate the representational styles in pairs, none of them might found to be predominant (Bengtsson and Wass 2011; Bowler 2017; Carman 2006). In order to tackle this limitation, Werner (2019) developed a methodologically innovative approach combining both these approaches by asking respondents first to rate each option separately and then in pairs. In addition, her research design employed an original survey experiment which confronted respondents with a situational vignette to disentangle the preferences and identify the primary one. This approach is certainly a step towards tackling the representational preferences according to their relevance in a reliable way. However, given the demands placed on respondents in completing an extensive questionnaire it is questionable how successful such a method would be to measure MPs' preferences in order to compare them with citizens.

Finally, it can be contested whether representatives and citizens are even addressing the same phenomenon when indicating their representational preferences. Voters' preferences might be biased due to their modest understanding of the institutional constraints under which MPs operate (Campbell and Lovenduski 2015, p. 694) whereas MPs can be so constrained by practical realities that they perceive representational models as being abstract and redundant. Hence, we easily end up setting voters' ideals against MPs' task descriptions (cf. Esaiasson 2000). The other possible source of ambiguity is the character of preferences since it seldom becomes evident whether both voters and MPs are revealing egotropic or sociotropic preferences. It could easily be the case that former mostly consider representation from the point of view of an individual citizen while the latter think of wider implications for representative democracy or other way around. This further means that interpreting the results of empirical studies of conguence in representational preferences is more complex than when assessing issue congruence between voters and their representatives.

\section{$<a>$ Congruence in representational preferences: empirical findings and their implications}


Despite methodological issues, we need to address the ultimate question: what does the high or low level of voter-MP congruence in representational preferences actually mean? (See von Schoultz and Wass 2016, p. 154-5). Because role preferences and real-life decision-making situations are two separate matters, congruence in preferences as such cannot be taken as an implication that the actions of MPs are necessarily in line with the expectations of voters. It merely indicates that both have similar normative concepts of representation. More objective measures of the behavior of MPs include such things as analyses of deliberations within parliamentary standing committees, rollcall voting or plenum speeches. MPs' preferences might also be sensitive to social desirability bias, mostly echoing the assumed expectations of voters for local representation or frustration with partyorientated representation. Finally, even a high degree of voter-MP congruence in representational preferences does not guarantee anything simply because when it comes to their legislative voting, representatives obey the instructions issued by their parties in most instances (von Schoultz and Wass 2016, p. 155). These are the key issues to bear in mind when discussing empirical findings in the field.

While there is substantial literature on MPs' perceptions of their parliamentary roles (for review, see Andeweg 2012; Brack et al. 2016) and a growing number of studies examining voters' expectations (André et al. 2010; Bengtsson and Wass 2010, 2011; Carman 2006, 2007; Dassonneville et al. 2020; Davidson 1970; Doherty 2013; Kornberg et al. 1980; McMurray and Parsons 1965; Patterson et al. 1975; Werner 2019), only a handful of analyses have focused on congruence between the two. Following the seminal Canadian study by Kornberg et al. (1980), Holmberg (1989) noticed that the members of the Swedish parliament and voters clearly diverged in relation to their views on preferred roles of the representatives. Whereas the role of party loyalists was prioritized by MPs (51\%) from three options available, only 14 percent of voters shared the same preference. For voters, the delegate role was the definite top preference, preferred by 56 percent, but only by 15 percent of MPs. However, both groups saw eye to eye about the role of an independent trustee, preferred by around 30 percent.

Over a decade later, Méndez-Lago and Martínez (2002) found a considerable congruence gap based on surveys conducted separately among Spanish MPs and voters in 1997. The discrepancy in representational preferences was most pronounced in relation to the geographical focus: 42 percent of MPs perceived that legislators should represent all the nation's citizens while only 28 percent considered all voters in their constituency to be the primary focus. Less than five percent preferred constituency-centered representation, while support for national representation was almost equally large among citizens. Furthermore, less than ten percent of Spanish MPs prioritized their party as a representational focus as opposed to around 25 percent of the voters. In turn, MP-voter congruence in functionally defined representation of specific interest groups appeared to be quite high: among both groups only a few percent regarded a specific social group to be the most important focus of representation.

It took another decade until the next study, which was conducted in the context of UK single-member constituencies (Campbell and Lovenduski 2015). It revealed the level of MP-voter congruence in the preference for representational roles to be much higher than the authors initially expected. From a pre-defined list, both groups prioritized constituency-orientated activities, although such an emphasis was slightly more popular among voters than among MPs. Party-orientated activities, such as supporting MP's party in parliament and taking part in parliamentary debates were both ranked first by under less than five percent among MPs and voters. The authors, however, recommended treating the results with caution as they do not necessarily travel across electoral systems (see Campbell and Lovenduski 2015, p. 705). In addition, the fact that all MPs included in the survey were backbenchers might have biased the results in favor of the constituency orientation. 
In their investigation of the Finnish open-list proportional representation (PR) system with mandatory preferential voting, von Schoultz and Wass (2016) matched two surveys including identical questions concerning the focus of representation posed to voters and candidates. The most popular focus among both groups turned out to be the national perspective, reflecting the constitutional principle of citizen representation, while constituency-orientated representation was the second most popular alternative. Party, in turn, seemed to be downplayed in the Finnish context with a surprisingly low eight percent of candidates considering it to be their primary focus. Representation of specific interest groups was the least popular alternative, which only a marginal proportion of candidates and voters regarded as the priority. Based on the overall ranking of the different foci made by candidates and voters, the authors also calculated many-to-many congruence using a measure developed by Golder and Stramski (2010). On average, the distribution of preferences for each of the four representational foci was strikingly similar between voters and candidates. The highest level of congruence, close to an identical preference distribution (ranking), was found for the party focus. The lowest, although still notable, level of congruence concerned the constituency perspective.

While it is impossible to draw strong conclusions from a handful of studies conducted in different electoral systems at different times, some observations seem obvious. First, party-focused representation has low ranking, be it assessed by voters or political elites. This certainly makes sense in open-list systems, such as Finland, where around 40 percent of voters consider candidates to be more important for their vote choice than the party (Isotalo et al. 2019, p. 16). It might also reflect the desire of representatives to have more room for maneuver from the party whip. Second, particularly the results from Finnish and the UK indicate a reasonable match between citizens and political elites in terms of their representational preferences. The size of this match is somewhat higher especially when contrasted with the level of voter-MP congruence on some policy issues. Whereas studies of issue agreement have detected a high correspondence between parties and voters on issues closely related to the left-right dimension (Dingler et al. 2019; Dolný and Baboš 2015; Reher 2018), noticeable discrepancies have previously been observed concerning EU and immigration (e.g., Lefkofridi and Horvath 2012; Mattila and Raunio 2012). Finally, it is unclear what voter-MP congruence in representational preferences ultimately means, and what implications it could potentially have. This is what we turn to next.

\section{<a> A link between voter-MP congruence in representational preferences and satisfaction with democracy}

Despite the difference between voter-MP congruence in representational preferences and the actual congruence in voters' expectations and MPs' real-life actions, there are reasons to assume that even the former can influence the legitimacy of the representational process. A recent study by Arnesen and Peters (2018), based on survey experiments, suggests that citizens are more willing to accept political decisions when they are made in line with descriptive representation, namely by a group of people like them. It thus seems reasonable to assume that the same logic would apply to representational roles: once the outcome of the policy-making process has been pursued (even if not necessarily reached in a fashion that corresponds citizens' representational expectations), it appears to be more legitimate. From that perspective, voter-MP congruence in representational preferences can be seen as being one component of the perceived responsiveness which affects decision acceptance among citizens (cf. Esaiasson et al. 2017).

An even bigger question relates to the extent to which citizens' satisfaction with the representational processes influences their overall satisfaction with democracy. In fact, there is evidence that if MPs fulfil their representative roles in line with citizens' expectations, people are increasingly likely to be 
satisfied with the way democracy works in their country (Aarts and Thomassen 2008; Blais et al. 2017; Brunell and Buchler 2009; Dahlberg et al. 2015; Ruiz-Rufino 2013). The link also works the other way around: a failure to meet citizens' expectations leads to disappointment which may damage the legitimacy of the entire democratic regime (Bowler and Karp 2004; Vivyan and Wagner 2016).

Could voter-MP congruence in representational preferences thus be used as an indicator of citizens' satisfaction with democracy? It is generally argued that citizens are happier about the quality of representation when they perceive their preferences being promoted by policy-makers (Anderson et al. 2005; Miller 1974). This usually happens in the systems with a high degree of ideological congruence between citizens and their elected representatives (Curini et al. 2012; Dahlberg and Holmberg 2014; Ezrow and Xezonakis 2011; Kim 2009) which increases the chances of political elites to address the issues in line with citizens' preferences (Jones and Baumgartner 2004; Spoon and Klüver 2014).

Having said that, citizens' preferences for representation are not necessarily fully aligned with their policy preferences at every point in time (Jennings and Wlezien 2015). While representational preferences are tied to more fundamental values and thus more stable (Adams 2012; Tavits 2007), policy preferences may reflect the urgency responding to current events and ever-changing social realities (McCombs 1999). Therefore, even when voter-MP representational preferences are largely congruent, they may not agree at the level of policy priorities and under such circumstances voters' satisfaction with democracy tends to decrease (Reher 2015, 2016). It thus seems that even though representational congruence is an important precondition for citizens' satisfaction with political representation and democracy at large (Jennings and Wlezien 2015; Jones and Baumgartner 2004; Spoon and Klüver 2014), it cannot beat the role of issue agreement. The limited time incumbents have in office, the restricted capacity of political systems to process policy demands, and other limited resources make it crucial for legislators to be responsive to the saliency of particular interests as they are perceived by voters (Bevan and Jennings 2014; Esaiasson and Holmberg 1996; Hobolt and Klemmensen 2008). Otherwise, the voter-MP ideological congruence, let alone congruence in representational preferences, is not enough to be transformed into a positive evaluation of a democratic system by the people (Reher 2015, 2016).

\section{$<\mathbf{a}>$ Conclusions}

In this chapter, we have reviewed the existing literature on congruence between voters' and political elites' preferences for representational roles. When assessing the state of art in any field of study, a triple-loop model (see Argyris and Schön 1978) developed for organizational learning is a useful tool. In line with each loop, three questions needs to be addressed: (1) Are we doing (in this case measuring) things right?, (2) Are we doing (i.e., measuring) the right things, and (3) How do we decide what are the right things (measures)?

When applied to the study of congruence in representation, the answer to the first question is probably something like not necessarily. While the review of the literature on congruence in citizen-elite representational preferences reveals that there is a considerable overlap between the preferred representative roles among voters and legislators, especially when the degree of agreement is compared to the congruence over some policy issues, such as migration or EU, these findings are based on aggregated survey responses. However, the very nature of preference-aggregation process directs the focus to prevailing tendencies, leaving more marginal groups and opinions disregarded. Recent studies comparing survey responses to register-based indicators show that surveys underestimate socioeconomic differences and differences between men and women and natives and voters with a migrant background in electoral participation (Dahlgaard et al. 2019; Lahtinen et al. 
2019). The same observation may well apply to studies of representational preferences, particularly as the earlier research has shown that economically-disadvantaged citizens are the ones likely to be less committed to the principles of liberal democracy (Ceka and Magalhães 2019) and dissatisfied with democracy if their preferences are not reflected by democratic institutions (Han and Chang 2016).

The second question is equally tough: are we studying meaningful things when focusing on voterMP congruence in representational preferences? Our response is yes and no. As such, citizens' expectations of an ideal-type, non-contextualized role for MPs do not provide much information. MPs' own role perceptions are more revealing but in reality practical constraints, like party discipline, set limits to the extent to which these can be followed in real-life political processes. On the other hand, representative democracy is built on the assumption that elected representatives act on citizens' behalf and are accountable to voters. If the opportunities for voters to communicate their preferences directly to MPs are limited, political elites must rely on their instinct or other types of discretion in an attempt to accommodate their representational roles to anticipated expectations of voters. The success in such a shadow-boxing exercise can often have positive implications for the legitimacy and stability of the entire democratic system (Easton 1965; Lipset 1959). Hence, it makes sense for MPs to know what type of representation citizens want and for citizens to know what MPs can deliver. The level of congruence between these two is important knowledge for those interested in the legitimacy of democratic processes since vocal dissidents, no matter how small in number, may be crucial for the sustainability of democratic regimes because their disappointment can fuel the emergence of and support for anti-establishment forces. In short, studying congruence in representational preferences enhances the understanding of representation as an active reciprocal exchange instead of static power relations (cf. Castiglione and Warren 2019, p. 34-5).

Finally, how can we decide what type of congruence in what types of representational role is worthy of investigation? The strong quantitative tradition in the research of political elites' and citizens' perception of representation follows a predominantly deductive approach. The concepts of representation are mostly theorized by scholars, some models dating back to early days of representative democracy. In empirical studies, these are then followed up with large samples of survey respondents. An inductive perspective, which would firstly approach citizens or elected representatives without a priori expectations and subsequently turn their inputs into theory formation, is much less popular among scholars of representation. (However, see Lefébure and Rozenberg 2011). As a result, we possess a limited set of empirical material which would unambiguously confirm that the scholars' view of representative roles is consistent with the real demands of citizens or of their representatives, even though the same concepts have been repeatedly utilized in this research agenda for decades.

These blank spots should stimulate researchers for future work. The research of representational congruence constitutes a field of potentially high theoretical and social relevance and therefore deserves to have continuous attention from scholars. There is a lot to be expected from the studies of representational expectations. 


\section{$<a>$ Acknowledgements}

The authors acknowledge the funding provided by the Strategic Research Council of the Academy of Finland (grant no 312710).

\section{References}

Aarts, K. and J. Thomassen (2008), 'Satisfaction with democracy: Do institutions matter?', Electoral Studies, 27 (1), 5-18.

Adams, J. (2012), 'Causes and Electoral Consequences of Party Policy Shifts in Multiparty Elections: Theoretical Results and Empirical Evidence', Annual Review of Political Science, 15 (1), 40119.

Anderson, C. J., A. Blais, S. Bowler, T. Donovan and O. Listhaug (2005), Losers' Consent: Elections and Democratic Legitimacy, Oxford: Oxford University Press.

Andeweg, R. B. (2011), 'Approaching Perfect Policy Congruence: Measurement, Development, and Relevance for Political Representation', in M. Rosema, B. Denters, and K. Aarts (eds), How Democracy Works: Political Representation and Policy Congruence in Modern Societies, Amsterdam: Amsterdam University Press, pp. 39-52.

Andeweg, R. B. (2012), 'The consequences of representatives' role orientations: attitudes, behaviour, perceptions', in M. Blomgren and O. Rozenberg (eds), Parliamentary Roles in Modern Legislatures, Oxon: Routledge, pp. 66-84.

André, A., S. Depauw and G. Sandri (2010), 'Les attitudes des citoyens vis-à-vis des services des élus aux électeurs', in P. Delwit, M. Hooghe, S. Walgrave, and K. Deschouwer (eds), Les Voix Du Peuple. Le Comportement Électoral Au Scrutin Du 10 Juin 2009, Bruxelles: Editions de 1’Université de Bruxelles, pp. 199-220.

Ankersmit, F. R. (2002), Political Representation, Stanford, CA: Stanford University Press.

Argyris, C. and D. A. Schön (1978), Organizational Learning: A Theory of Action Perspective, Reading: Addison-Wesley.

Arnesen, S. and Y. Peters (2018), 'The Legitimacy of Representation: How Descriptive, Formal, and Responsiveness Representation Affect the Acceptability of Political Decisions', Comparative Political Studies, 51 (7), 868-99.

Bengtsson, Å. and H. Wass (2010), 'Styles of Political Representation: What Do Voters Expect?', Journal of Elections, Public Opinion and Parties, 20 (1), 55-81.

Bengtsson, Å. and H. Wass (2011), 'The Representative Roles of MPs: A Citizen Perspective', Scandinavian Political Studies, 34 (2), 143-67.

Bevan, S. and W. Jennings (2014), 'Representation, agendas and institutions', European Journal of Political Research, 53 (1), 37-56.

Blais, A., A. Morin-Chassé and S. P. Singh (2017), 'Election outcomes, legislative representation, and satisfaction with democracy', Party Politics, 23 (2), 85-95.

Bowler, S. (2017), 'Trustees, Delegates, and Responsiveness in Comparative Perspective', Comparative Political Studies, 50 (6), 766-93.

Bowler, S. and Karp (2004), 'Politicians, Scandals, and Trust in Government', Political Behavior, 26 


$$
\text { (3), 271-287. }
$$

Brack, N., O. Costa and E. Kerrouche (2016), 'MPs between territories, assembly and party Investigating parliamentary behaviour at the local level in France, Belgium and Germany', French Politics, 14 (4), 395-405.

Brack, N., O. Costa and C. Pequito Teixeira (2012), 'Attitudes Towards the Focus and Style of Political Representation among Belgian, French and Portuguese Parliamentarians', Representation, 48 (4), 387-402.

Brito Vieira, M. and D. Runciman (2008), Representation, Cambridge, UK: Polity.

Brunell, T. L. and J. Buchler (2009), 'Ideological representation and competitive congressional elections', Electoral Studies, 28 (3), 448-57.

Campbell, R. and J. Lovenduski (2015), 'What Should MPs Do? Public and Parliamentarians' Views Compared', Parliamentary Affairs, 68 (4), 690-708.

Carman, C. J. (2006), 'Public Preferences for Parliamentary Representation in the UK: An Overlooked Link?', Political Studies, 54 (1), 103-22.

Carman, C. J. (2007), 'Assessing Preferences for Political Representation in the US', Journal of Elections, Public Opinion and Parties, 17 (1), 1-19.

Castiglione, D. and M. E. Warren (2019), 'Rethinking democratic representation: eight theoretical issues and a postscript1', in L. Disch, M. van de Sande, and N. Urbinati (eds), The Constructivist Turn in Political Representation, Edinbourgh: Edinburgh University Press, pp. 21-47.

Ceka, B. and P. C. Magalhães (2019), 'Do the Rich and the Poor Have Different Conceptions of Democracy? Socioeconomic Status, Inequality, and the Political Status Quo', Comparative Politics, accessed at https://doi.org/10.5129/001041520X15670823829196.

Curini, L., W. Jou and V. Memoli (2012), 'Satisfaction with democracy and the winner/loser debate: The role of policy preferences and past experience', British Journal of Political Science, 42 (2), 241-61.

Dahlberg, S. and S. Holmberg (2014), 'Democracy and Bureaucracy: How their Quality Matters for Popular Satisfaction', West European Politics, 37 (3), 515-37.

Dahlberg, S., J. Linde and S. Holmberg (2015), 'Democratic Discontent in Old and New Democracies: Assessing the Importance of Democratic Input and Governmental Output', Political Studies, 63 (1_suppl), 18-37.

Dahlgaard, J. O., J. H. Hansen, K. M. Hansen and Y. Bhatti (2019), 'Bias in Self-reported Voting and How it Distorts Turnout Models: Disentangling Nonresponse Bias and Overreporting Among Danish Voters', Political Analysis, 27 (4), 590-8.

Dalton, R. J., D. Farrell and I. McAllister (2011), 'The dynamics of democratic representation', in M. Rosema, B. Denters, and K. Aarts (eds), How Democracy Works: Political Representation and Policy Congruence in Modern Societies, Amsterdam: Amsterdam University Press, pp. 21-37.

Dassonneville, R., A. Blais, S. Sevi and J.-F. Daoust (2020), 'How Citizens Want Their Legislator to Vote', Legislative Studies Quarterly, accessed at https://doi.org/10.1111/lsq.12275.

Davidson, R. H. (1970), 'Public Prescriptions for the Job of Congressman', Midwest Journal of Political Science, 14 (4), 648-66. 
Dingler, S. C., C. Kroeber and J. Fortin-Rittberger (2019), 'Do parliaments underrepresent women's policy preferences? Exploring gender equality in policy congruence in 21 European democracies', Journal of European Public Policy, 26 (2), 302-21.

Doherty, D. (2013), 'To Whom Do People Think Representatives Should Respond: Their District or the Country?', Public Opinion Quarterly, 77 (1), 237-55.

Dolný, B. and P. Baboš (2015), 'Voter-Representative Congruence in Europe: A Loss of Institutional Influence?', West European Politics, 38 (6), 1274-304.

Dovi, S. (2007), The Good Representative, Oxford: Blackwell Publishers.

Easton, D. (1965), A Systems Analysis of Political Life, New York: John Wiley.

Esaiasson, P. (2000), 'How Members of Parliament Define Their Task', in P. Esaiasson and K. Heidar (eds), Beyond Westminster and Congress: The Nordic Experience, Columbus, OH: Ohio State University Press, pp. 51-82.

Esaiasson, P., M. Gilljam and M. Persson (2017), 'Responsiveness Beyond Policy Satisfaction: Does It Matter to Citizens?', Comparative Political Studies, 50 (6), 739-65.

Esaiasson, P. and S. Holmberg (1996), Representation from Above: Members of Parliament and Representative Democracy in Sweden, Aldershot: Dartmouth.

Eulau, H. and P. D. Karps (1977), 'The Puzzle of Representation: Specifying Components of Responsiveness', Legislative Studies Quarterly, 2 (3), 233.

Eulau, H., J. C. Wahlke, W. Buchanan and L. C. Ferguson (1959), 'The Role of the Representative: Some Empirical Observations on the Theory of Edmund Burke', American Political Science Review, 53 (3), 742-56.

Ezrow, L. and G. Xezonakis (2011), 'Citizen Satisfaction With Democracy and Parties' Policy Offerings', Comparative Political Studies, 44 (9), 1152-78.

Golder, M. and J. Stramski (2010), 'Ideological Congruence and Electoral Institutions', American Journal of Political Science, 54 (1), 90-106.

Han, S. M. and E. C. C. Chang (2016), 'Economic inequality, winner-loser gap, and satisfaction with democracy', Electoral Studies, 44, 85-97.

Hobolt, S. B. and R. Klemmensen (2008), 'Government Responsiveness and Political Competition in Comparative Perspective', Comparative Political Studies, 41 (3), 309-37.

Holmberg, S. (1989), 'Political Representation in Sweden', Scandinavian Political Studies, 12 (1), $1-36$.

Hurley, P. A. (1982), 'Collective Representation Reappraised', Legislative Studies Quarterly, 7 (1), 119-36.

Isotalo, V., T. Järvi, Å. von Schoultz and P. Söderlund (2019), The Finnish Voter: 2000-2019.

Jennings, W. and C. Wlezien (2015), 'Preferences, Problems and Representation', Political Science Research and Methods, 3 (3), 659-81.

Jones, B. D. and F. R. Baumgartner (2004), 'Representation and Agenda Setting', Policy Studies Journal, 32 (1), 1-24.

Judge, D. (1999), Representation: Theory and Practice in Britain, London: Routledge. 
Kim, M. (2009), 'Cross-National Analyses of Satisfaction with Democracy and Ideological Congruence', Journal of Elections, Public Opinion and Parties, 19 (1), 49-72.

Kornberg, A., H. D. Clarke and A. Goddard (1980), 'Parliament and the representational process in contemporary Canada', in H. D. Clarke, C. Campbell, F. Q. Quo, and A. Goddard (eds), Parliament, Policy and Representation, Toronto: Methuen, pp. 1-24.

Kurland, P. B. and R. Lerner (eds.) (1987), 'Edmund Burke, Speech to the Electors of Bristol', The Founders' Constitution, Volume 1, Chapter 13, Document 7, Chicago, IL: University of California Press, accessed http:/presspubs.uchicago.edu/founders/documents/v1ch13s7.html.

Lahtinen, H., P. Martikainen, M. Mattila, H. Wass and L. Rapeli (2019), 'Do Surveys Overestimate or Underestimate Socioeconomic Differences in Voter Turnout? Evidence from Administrative Registers', Public Opinion Quarterly, 83 (2), 363-85.

Lefébure, P. and O. Rozenberg (2011), 'Representatives in the Eyes of their Constituents. A Qualitative Analysis of French Citizens' Views', in Paper Presented at the IPSA-ECPR Joint Conference. 16-19, Sao Paulo. February 2011.

Lefkofridi, Z. and K. Horvath (2012), 'Migration issues and representation in European liberal democracies', Representation, 48 (1), 29-46.

Lipset, S. M. (1959), 'Some Social Requisites of Democracy: Economic Development and Political Legitimacy', American Political Science Review, 53 (1), 69-105.

Louwerse, T. and R. Andeweg (2020), 'Measuring Representation: Policy Congruence', in M. Cotta and F. Russo (eds), Handbook of Political Representation, Edward Elgar Publishing.

Mansbridge, J. (2003), 'Rethinking Representation', American Political Science Review, 97 (4), 515 28.

Mattila, M. and T. Raunio (2012), 'Drifting Further Apart: National Parties and their Electorates on the EU Dimension', West European Politics, 35 (3), 589-606.

McCombs, M. (1999), 'Personal involvment with issues on the ublic agenda', International Journal of Public Opinion Research, 11 (2), 152-68.

McMurray, C. D. and M. B. Parsons (1965), 'Public Attitudes Toward the Representational Roles of Legislators and Judges', Midwest Journal of Political Science, 9 (2), 167-85.

Méndez-Lago, M. and A. Martínez (2002), 'Political Representation in Spain: An Empirical Analysis of the Perception of Citizens and MPs', The Journal of Legislative Studies, 8 (1), 63-90.

Miller, A. H. (1974), 'Political Issues and Trust in Government: 1964-1970', American Political Science Review, 68 (3), 951-72.

Miller, W. E. and D. E. Stokes (1963), 'Constituency Influence in Congress', American Political Science Review, 57 (1), 45-56.

Önnudóttir, E. H. (2016), 'Political parties and styles of representation', Party Politics, 22 (6), 732 45.

Patterson, S. C., R. D. Hedlund and G. R. Boynton (1975), Representatives and Represented, New York: Wiley.

Pitkin, H. (1967), The Concept of Representation, Berkeley: University of California Press. 
Reher, S. (2015), 'Explaining cross-national variation in the relationship between priority congruence and satisfaction with democracy', European Journal of Political Research, 54 (1), 160-81.

Reher, S. (2016), 'The Effects of Congruence in Policy Priorities on Satisfaction with Democracy The Effects of Congruence in Policy Priorities on Satisfaction with Democracy', Journal of Elections, Public Opinion and Parties Parties, 26 (1), 40-57.

Reher, S. (2018), 'Gender and opinion-policy congruence in Europe', European Political Science Review, 10 (4), 613-35.

Ruiz-Rufino, R. (2013), 'Satisfaction with Democracy in Multi-ethnic Countries: The Effect of Representative Political Institutions on Ethnic Minorities', Political Studies, 61 (1), 101-18.

Saward, M. (2010), The Representative Claim, Oxford: Oxford University Press.

Spoon, J.-J. and H. Klüver (2014), 'Do parties respond? How electoral context influences party responsiveness', Electoral Studies, 35, 48-60.

Stimson, J. (2007), Perspectives on Representation: Asking the Right Questions and Getting the Right Answers, Oxford: Oxford University Press.

Tavits, M. (2007), 'Principle vs. Pragmatism: Policy Shifts and Political Competition', American Journal of Political Science, 51 (1), 151-65.

Thomassen, J. (1994), 'Empirical Research into Political Representation: Failing Democracy orFailing Models?', in M. K. Jennings and T. E. Mann (eds), Elections at Home and Abroad, Ann Arbor, MI: University of Michigan Press, pp. 237-65.

Urbinati, N. and M. E. Warren (2008), 'The Concept of Representation in Contemporary Democratic Theory', Annual Review of Political Science, 11 (1), 387-412.

Vivyan, N. and M. Wagner (2016), 'House or home? Constituent preferences over legislator effort allocation', European Journal OfPolitical Research, 55 (1), 81-99.

von Schoultz, Å. and H. Wass (2016), 'Beating Issue Agreement: Congruence in the Representational Preferences of Candidates and Voters', Parliamentary Affairs, 69 (1), 136-58.

Weissberg, R. (1978), 'Collective vs. Dyadic Representation in Congress', American Political Science Review, 72 (2), 535-47.

Werner, A. (2019), 'Voters' preferences for party representation: Promise-keeping, responsiveness to public opinion or enacting the common good', International Political Science Review, 40 (4), 486-501. 